\title{
The brachiopod succession through the Silurian-Devonian boundary beds at Dnistrove, Podolia, Ukraine
}

\author{
Andrzej Baliński \\ Acta Palaeontologica Polonica 57 (4), 2012: 897-924 doi: http://dx.doi.org/10.4202/app.2011.0138
}

In the classic section across the Silurian-Devonian boundary at Dnistrove (Podolia, Ukraine) the brachiopod fauna has never been studied in detail. This paper presents results of research on brachiopods from this important locality and time interval. Bed-by-bed collecting has enabled the detailed distribution of brachiopod taxa through the boundary beds to be revealed. Generally, the reference section at Dnistrove yields rather scarce but often well preserved brachiopods. Dayia bohemica and Dnestrina gutta can be regarded as characteristic species

for the uppermost Silurian. A relatively high-diversity but low-abundance brachiopod fauna occurs in the lowest $1.8 \mathrm{~m}$ of the earliest Devonian. Only three forms have been found to cross the Silurian-Devonian boundary: the strophomenide Plectodonta (Plectodonta) mariae pantherae subsp. nov., the atrypide Gracianella (Sublepida) paulula sp. nov., and the spiriferide Howellella (Howellella) latisinuata. Arelatively narrow brachiopod-rich interval at $5.5 \mathrm{~m}$ above the Silurian-Devonian boundary yields 16 brachiopod species which probably indicate a setting near the lower limit of the photic zone equivalent to the Benthic Assemblage 3-4 boundary. Two new species and one new subspecies are described: Skenidioides tatyanae, Plectodonta (Plectodonta) mariae pantherae, and Gracianella (Sublepida) paulula.

Key words: Brachiopoda, palaeoenvironments, Silurian-Devonian boundary, Podolia, Ukraine.

Andrzej Baliński [balinski@twarda.pan.pl], Instytut Paleobiologii PAN, ul. Twarda 51/55, PL-00-818 Warszawa, Poland.

This is an open-access article distributed under the terms of the Creative Commons Attribution License (for details please see creativecommons.org), which permits unrestricted use, distribution, and reproduction in any medium, provided the original author and source are credited. 
FoF 5 Full text $(2,544.2 \mathrm{kB})$ 